\title{
Evaluation of Prescribing Patterns of Antibiotics Using Selected Indicators for Antimicrobial Use in Hospitals and the Access, Watch, Reserve (AWaRe) Classification by the World Health Organization
}

\author{
Hastanelerde Antimikrobiyal Kullanımı ile İlgili Seçilmiş Göstergeler ve \\ Dünya Sağlık Örgütü Tarafından Tanımlanan AWaRe Sınıflandırması \\ Kullanılarak Antibiyotik Reçeteleme Kalıplarının Değerlendirilmesi
}

\author{
(D) Vinodkumar MUGADA*, (D) Varsha MAHATO, (D) Damayanthi ANDHAVARAM, (D) Sairam Mouli VAJHALA \\ Vignan Institute of Pharmaceutical Technology, Department of Pharmacy Practice, Andhra Pradesh, India
}

\section{ABSTRACT}

Objectives: Antibiotic resistance poses a significant threat to the world, and irrational use of antibiotics is a major contributing factor. Evaluation of antimicrobial use is underway with the help of indicators and the World Health Organization (WHO) classification of antibiotics into Access, Watch, and Reserve (AWaRe) categories. We aimed to evaluate the prescribing pattern of antibiotics using the AWaRe classification by the WHO and selected indicators for antimicrobial use in hospitals.

Materials and Methods: A total of 1.000 prescriptions were analyzed during the study for antibiotic prescribing patterns. Antibiotic consumption was calculated using defined daily dose (DDD) methodology. The prescribing pattern was evaluated using the WHO classification of antibiotics into the categories AWaRe and using selected indicators (hospital and prescribing) for antimicrobial use in hospitals.

Results: A total of 1.128 antibiotics were prescribed during the study. The $19-44$ age group was prescribed a high number of antibiotics ( $n=510$ ). Females were prescribed a high number of antibiotics compared with males $(n=602)$. Azithromycin was the most commonly consumed antibiotic (14.97 DDD/1000/day). Four antibiotics from the Access category and five from the Watch category were prescribed in the study. The Watch category of antibiotics were consumed in a high number. There were no standard treatment guidelines in the hospital. In all, $98.0 \%$ of antibiotics were consistent with the hospital formulary and prescribed under generic names. The average number of antibiotics prescribed per patient was 1.12. The average duration of antimicrobial treatment was 5.24 days. The percentage of patients prescribed antimicrobials for pneumonia in accordance with treatment guidelines was $13.28 \%$.

Conclusion: Irrational use of antibiotics exists in hospitals. There is a need to maintain standard treatment guidelines in the hospital because it prevents irrational use of antibiotics.

Key words: Access, Watch, Reserve, indicator, prescribing, antibiotic, evaluation, hospital, WHO

Öz

Amaç: Antibiyotik direnci dünya için önemli bir tehdit olușturmaktadır ve akılcı olmayan antibiyotik kullanımı bu duruma önemli katkıda bulunan faktördür. Antimikrobiyal kullanımının değerlendirilmesi çeșitli göstergeler ve Dünya Sağlık Örgütü’nün (DSÖ) antibiyotiklerin “Erişim, İzleme ve Rezerv [Access, Watch ve Reserve (AWaRe)]" kategorilerine göre sınıflandırılmasının kullanılmasıyla devam etmektedir. DSÖ'nün AWaRe sınıflandırmasını kullanarak antibiyotik reçeteleme modelini ve hastanelerde antimikrobiyal kullanımı için seçilen göstergeleri değerlendirmeyi amaçladık.

Gereç ve Yöntemler: Çalışma süresinde antibiyotik reçeteleme modelleri için toplam 1,000 reçete analiz edildi. Antibiyotik tüketimi, tanımlanan günlük doz metodolojisi (DDD) kullanılarak hesaplandı. Reçeteleme paterni, DSÖ antibiyotik sınıflandırması kullanılarak AWaRe kategorilerine göre ve hastanelerde antimikrobiyal kullanımı ile ilgili seçilen göstergeler (hastane ve reçete yazma) kullanılarak değerlendirildi. 
Bulgular: Çalışma sırasında toplam 1,128 antibiyotik reçete edildi. On dokuz-kırk dört yaş grubuna fazla sayıda antibiyotik reçete edildi ( $n=510$ ). Kadınlara erkeklere $(n=602)$ kıyasla çok sayıda antibiyotik reçete edildi. Azitromisin en sık tüketilen antibiyotiktir (14,97 DDD/1000/gün). Çalışmada Access kategorisinden dört ve Watch kategorisinden beş antibiyotik reçete edildi. Watch kategorisindeki antibiyotikler yüksek sayıda tüketildi. Hastanede standart tedavi yönergeleri yoktu. Toplamda, antibiyotiklerin \%98, ı hastane formüleriyle uyumluydu ve jenerik isimler altında reçete edildi. Hasta başına reçete edilen ortalama antibiyotik sayısı 1,12 idi. Ortalama antimikrobiyal tedavi süresi 5,24 gündü. Tedavi kılavuzlarına uygun olarak pnömoni için antimikrobiyal reçete edilen hastaların yüzdesi \%13,28 idi.

Sonuç: Hastanelerde akılcı olmayan antibiyotik kullanımı mevcuttur. Mantıksız antibiyotik kullanımını engellediği için hastanede standart tedavi kurallarının sürdürülmesine ihtiyaç vardır.

Anahtar kelimeler: Erișim, Saat, Rezerv, gösterge, reçeteleme, antibiyotik, değerlendirme, hastane, DSÖ

\section{INTRODUCTION}

Antibiotic resistance poses a significant threat to global public health ${ }^{1,2}$ and was given special mention as a serious threat to public health, economic growth, and global economic stability. ${ }^{3}$ Increased antibiotic resistance rates may lead to prolonged hospitalization and duration of treatment, as well as increased treatment costs and mortality. ${ }^{4}$ The major contributing factor to this resistance is inappropriate or irrational use of antibiotics. Irrespective of the alarming increase in resistance, there is an increased irrational prescribing practice of antibiotics across different regions. ${ }^{5-13}$ In 2017, the World Health Organization (WHO) commissioned comprehensive reviews on antibiotic use for specific infections in order to update the Essential Medicines List. $^{14}$ The expert committee then formulated the Access, Watch, Reserve (AWaRe) classification of antibiotics with the goals of better accessibility and clinical outcomes, a decreased probability of antimicrobial resistance, and safeguarding the effectiveness of last-resort antibiotics. ${ }^{15}$ Access group of antibiotics are first and second choices for empirical treatment of 21 common or severe clinical syndromes. The Access group of antibiotics are a core set of antibiotics and should always be made available in every place at an appropriate quality, dose, duration, formulation, and price. The Watch group includes antibiotics with higher toxicity concerns or resistance potential compared with the Access group. The Watch group antibiotics assist the development of tools for stewardship at the local, national, and global levels. The Reserve group antibiotics are last-resort options and are used for specific patients and clinical settings in case of failure of other alternatives. Prioritizing this group as key targets of high-intensity national and international stewardship programs preserves their effectiveness. ${ }^{15}$ Thus, the AWaRe index help to estimate the relative use of narrowspectrum and broad-spectrum antibiotics. The Strengthening Pharmaceutical Systems (SPS) Program also developed selected indicators for investigating antimicrobial use in hospitals, which complements the existing WHO indicators of outpatient antimicrobial use. These indicators provide a simple tool for fast and assuredly figuring out critical aspects of antimicrobial use and to recognize problems with antibiotic use in hospitals. ${ }^{16}$ So, we aimed to evaluate the prescribing pattern of antibiotics using the WHO AWaRe classification and selected indicators for investigating antimicrobial use in hospitals using the SPS Program.

\section{MATERIALS AND METHODS}

A descriptive, cross-sectional study was conducted on 1.000 patients with various diseases in a tertiary care hospital, for a duration of six months (08/01/2019 to 01/31/2020). The study was approved by the Institutional Human Ethics Committee (VIPT/IEC/61/2019). Prescriptions containing at least one antibiotic, prescribed to patients of all ages, and in various departments were included in the study. Prescriptions without antibiotics were excluded from the study. Simple random sampling was used to select prescriptions. The estimated sample size was 651 (margin of error 5\%, confidence level $99 \%$, population size 324,000 , and response distribution $50 \%$ ). However, we collected data for 1.000 prescriptions. The aim of the study was explained clearly to the patients and an informed consent form obtained from willing patients. Sociodemographic data including age and gender, and clinical details including name of the department, diagnosis, name of the antibiotic, dose, indication etc. were collected from the patient's prescription.

The WHO AWaRe classification (2019) was used to evaluate the rational use of antibiotics. Selected indicators for antimicrobial use for hospitals (hospital indicators and prescribing indicators) developed by the SPS Program was used to investigate antimicrobial use. The defined daily dose (DDD) per 1000 inhabitants per day was calculated using the following formula. Descriptive statistics (mean and standard deviation) were calculated using Minitab (version 18.0).

$\mathrm{DDD} / 1000 /$ day $=\frac{\text { Total number of dosage units prescribed } * \text { Dosage strength } * 1000}{D D D * \text { Duration of the study } * \text { Total sample size }}$

\section{RESULTS}

A total of 1.128 antibiotics were prescribed during the study. The mean age of the patients in our study was $33.04 \pm 18.59$ years. Patients in the 19-44 age group were prescribed with a high number of antibiotics ( $n=510,45.21 \%$ ) (Table 1$)$. Females were prescribed with a higher percentage of antibiotics than males $(53.47 \%$ vs. $46.63 \%$, respectively, Table 2). The general medicine department consumed a higher proportion of antibiotics (36.79\%, Table 3).

The DDD for azithromycin was high relative to that of other antibiotics (14.97 DDD/1000/day, Table 4). Four antibiotics from the Access category and five from the Watch category of the AWaRe classification were prescribed (Table 5). Standard 
Table 1. Age-wise distribution of antibiotics in patients

\begin{tabular}{|c|c|c|c|c|c|c|}
\hline S. no. & Name of the antibiotic & $1-18$ years & $19-44$ years & $45-63$ years & $\geq 64$ years & Total (\%) \\
\hline 1 & Amoxicillin + clavulanic acid & 131 & 122 & 51 & 18 & $322(28.54)$ \\
\hline 2 & Cefixime & 43 & 110 & 64 & 19 & $236(20.92)$ \\
\hline 3 & Azithromycin & 42 & 107 & 57 & 25 & $231(20.47)$ \\
\hline 4 & Metronidazole & 21 & 67 & 34 & 13 & 135 (11.96) \\
\hline 7 & Amoxicillin & 21 & 21 & 8 & 2 & $52(4.60)$ \\
\hline 8 & Doxycycline & 3 & 9 & 6 & 1 & $19(1.68)$ \\
\hline 9 & Norfloxacin & 2 & 6 & 3 & 0 & $11(0.97)$ \\
\hline
\end{tabular}

$\mathrm{n}$ : Number, \%: Percentage

\section{Table 2. Gender-wise distribution of antibiotics}

\begin{tabular}{lllll} 
S. no. & Name of the antibiotic & Males & Females & Total \\
\hline 1 & $\begin{array}{l}\text { Amoxicillin + clavulanic } \\
\text { acid }\end{array}$ & 135 & 187 & 322 \\
\hline 2 & Cefixime & 112 & 124 & 236 \\
\hline 3 & Azithromycin & 108 & 123 & 231 \\
\hline 4 & Metronidazole & 75 & 60 & 135 \\
\hline 5 & Ciprofloxacin & 30 & 36 & 66 \\
\hline 6 & Ofloxacin & 31 & 25 & 56 \\
\hline 7 & Amoxicillin & 26 & 26 & 52 \\
\hline 8 & Doxycycline & 6 & 13 & 19 \\
\hline 9 & Norfloxacin & 3 & 8 & 11 \\
\hline & n (\%) & 526 & $\begin{array}{l}602 \\
(53.37)\end{array}$ & 1128 \\
\hline
\end{tabular}

n: Number, \%: Percentage

treatment guidelines for infectious diseases and essential medicines were listed in the hospital. The average number of days that a set of key antimicrobials was out of stock was 3.2 days/month. In all, $98.3 \%$ of key antimicrobials were available on the day of the study (Table 6). The average number of antibiotics prescribed per hospitalization was 1.12. In all, 98\% of antimicrobials were consistent with the hospital formulary list and were prescribed by their generic names. In all, 13.28\% of antimicrobials for pneumonia patients were prescribed in accordance with standard treatment guidelines (Table 7 ).

\section{DISCUSSION}

We observed a high antibiotic prescribing rate in the 1944 patient age group. Interestingly, the rate of antibiotic prescription in the elderly was low $(7.35 \%)$. In general, the elderly are more vulnerable to infections, and thus a higher number of antibiotics are expected to be prescribed for them.
Table 3. Department-wise distribution of antibiotics

$\begin{array}{lllll}\text { S. Name of the G.M. ENT Ortho Ped Pul Others } & \end{array}$

no. antibiotic

\begin{tabular}{|c|c|c|c|c|c|c|c|}
\hline 1 & $\begin{array}{l}\text { Amoxicillin } \\
+ \text { clavulanic } \\
\text { acid }\end{array}$ & 94 & 124 & 14 & 35 & 22 & 33 \\
\hline 2 & Cefixime & 82 & 40 & 68 & 7 & 8 & 31 \\
\hline 3 & Azithromycin & 90 & 27 & 2 & 22 & 60 & 30 \\
\hline 4 & Metronidazole & 83 & 19 & 2 & 11 & 0 & 20 \\
\hline 5 & Ciprofloxacin & 28 & 25 & 3 & 0 & 1 & 9 \\
\hline 6 & Ofloxacin & 15 & 11 & 0 & 7 & 1 & 22 \\
\hline 7 & Amoxicillin & 14 & 21 & 2 & 5 & 3 & 7 \\
\hline 8 & Doxycycline & 2 & 0 & 11 & 0 & 0 & 6 \\
\hline 9 & Norfloxacin & 7 & 1 & 0 & 0 & 1 & 2 \\
\hline & n (\%) & $\begin{array}{l}415 \\
(36.79)\end{array}$ & $\begin{array}{l}268 \\
(23.75)\end{array}$ & $\begin{array}{l}102 \\
(9.04)\end{array}$ & $\begin{array}{l}87 \\
(7.71)\end{array}$ & $\begin{array}{l}96 \\
(8.51)\end{array}$ & $\begin{array}{l}160 \\
(14.18)\end{array}$ \\
\hline
\end{tabular}

n: Number, \%: Percentage, G.M.: General medicine, ENT: Ear, nose, throat, Ortho: Orthopedics, Ped: Pediatrics, Pul: Pulmonology, Others: Dermatology, general surgery, endocrinology, gastroenterology, nephrology, neurology, urology, dental, gynecology

Overprescription of antibiotics for the elderly is a common practice, and the physicians here were the exception to that, as was evident from Table 1. Females were prescribed a higher number of antibiotics than males $(53.37 \%$ vs. $46.3 \%$, respectively). Relatively speaking, females are less exposed to external environments than males; however, in our study, females were prone to more infections. The general medicine department covers a wide variety of diseases. Hence, the general medicine department consumed a higher percentage of antibiotics (36.79\%).

The commonly prescribed antibiotics in our study were amoxicillin + clavulanic acid $(n=322)$. Cefixime $(n=236)$ and azithromycin $(n=231)$ were the next most widely prescribed antibiotics. Atif et al. ${ }^{11}$ reported ceftriaxone as the most 
Table 4. Defined daily dose of each antibiotic along with the ATC code

\begin{tabular}{lllll} 
S. no. & $\begin{array}{l}\text { Name of the } \\
\text { antibiotic }\end{array}$ & ATC code & DDD & DDD/1000/day \\
\hline 1 & $\begin{array}{l}\text { Amoxicillin }+ \\
\text { clavulanic acid }\end{array}$ & J01CR02 & $1.5 \mathrm{~g}$ & 8.64 \\
\hline 2 & Cefixime & J01DD08 & $0.4 \mathrm{~g}$ & 9.17 \\
\hline 3 & Azithromycin & J01FA10 & $0.3 \mathrm{~g}$ & 14.97 \\
\hline 4 & Metronidazole & P01AB01 & $2 \mathrm{~g}$ & 3.15 \\
\hline 5 & Ciprofloxacin & J01MA02 & $1 \mathrm{~g}$ & 2.56 \\
\hline 6 & Ofloxacin & J01MA01 & $0.4 \mathrm{~g}$ & 2.17 \\
\hline 7 & Amoxicillin & J01CA04 & $1.5 \mathrm{~g}$ & 1.34 \\
\hline 8 & Doxycycline & J01AA02 & $0.1 \mathrm{~g}$ & 1.47 \\
\hline 9 & Norfloxacin & J01MA06 & $0.8 \mathrm{~g}$ & 0.42 \\
\hline & Total & - & - & 43.89 \\
\hline
\end{tabular}

ATC: Anatomic, therapeutic, chemical, DDD: Defined daily dose

Table 5. Categorization of antibiotics according to AWaRe classification by the WHO

\begin{tabular}{lllll} 
S. no. & $\begin{array}{l}\text { Name of the } \\
\text { antibiotic }\end{array}$ & Class of antibiotic & $\begin{array}{l}\text { AWaRe } \\
\text { category }\end{array}$ & $\begin{array}{l}\text { Listed } \\
\text { in EML }\end{array}$ \\
\hline 1 & $\begin{array}{l}\text { Amoxicillin }+ \\
\text { clavulanic acid }\end{array}$ & $\begin{array}{l}\text { Beta lactam-beta } \\
\text { lactamase inhibitor }\end{array}$ & Access & Yes \\
\hline 2 & Metronidazole & Imidazole & Access & Yes \\
\hline 3 & Amoxicillin & Penicillins & Access & Yes \\
\hline 4 & Doxycycline & Tetracycline & Access & Yes \\
\hline 5 & Cefixime & $\begin{array}{l}\text { Third generation } \\
\text { cephalosporin }\end{array}$ & Watch & Yes \\
\hline 6 & Azithromycin & Macrolide & Watch & Yes \\
\hline 7 & Ciprofloxacin & Fluoroquinolone & Watch & Yes \\
\hline 8 & Ofloxacin & Fluoroquinolone & Watch & No \\
\hline 9 & Norfloxacin & Fluoroquinolone & Watch & No \\
\hline
\end{tabular}

AWaRe: Access, Watch, Reserve, EML: Essential medicines list, WHO: World Health Organization

\section{Table 6. Hospital indicators for antimicrobial use in the} hospital

\begin{tabular}{lll} 
S. no. & Name of the indicator & Result \\
\hline 1 & $\begin{array}{l}\text { Existence of standard treatment } \\
\text { guidelines for infectious diseases }\end{array}$ & No \\
\hline 2 & $\begin{array}{l}\text { Existence of approved hospital formulary } \\
\text { list or essential medicines list }\end{array}$ & Yes \\
\hline 3 & $\begin{array}{l}\text { Availability of a set of key antimicrobials } \\
\text { in the hospital stores on the day of the } \\
\text { study }\end{array}$ & $98.30 \%$ \\
\hline 4 & $\begin{array}{l}\text { Average number of days that a key } \\
\text { antimicrobial was out of stock }\end{array}$ & 3.2 days/month \\
\hline
\end{tabular}

Table 7. Prescribing indicators for antimicrobial use in the hospital

\begin{tabular}{lll} 
S. no. & Name of the indicator & Result \\
\hline 1 & $\begin{array}{l}\text { Percentage of antimicrobials prescribed } \\
\text { consistent with the hospital formulary list }\end{array}$ & $98.00 \%$ \\
\hline 2 & $\begin{array}{l}\text { Average duration (in days) of prescribed } \\
\text { antimicrobial treatment }\end{array}$ & $5.24 \pm 1.35$ \\
\hline 3 & $\begin{array}{l}\text { Percentage of antimicrobials prescribed } \\
\text { by generic name }\end{array}$ & $98.00 \%$ \\
\hline 4 & $\begin{array}{l}\text { Average number of antibiotics prescribed } \\
\text { per hospitalization }\end{array}$ & 1.12 \\
\hline & $\begin{array}{l}\text { Percentage of patients with pneumonia } \\
\text { who are prescribed antimicrobials in }\end{array}$ & $13.28 \%$ \\
5 & $\begin{array}{l}\text { accordance with standard treatment } \\
\text { guidelines }\end{array}$ \\
\hline
\end{tabular}

commonly prescribed antibiotic (71.8\%). The most frequently prescribed antibiotic class was cephalosporins (81.5\%), while the most frequent antibiotic combination was ciprofloxacin + metronidazole $(52.1 \%)$. A repeated point prevalence survey on the appropriateness of antimicrobial prescribing reported that penicillins with beta-lactamase inhibitors were the most frequently prescribed antibiotics (30\%), which was in close agreement with the results of our study. ${ }^{6}$

Azithromycin (14.97 DDD/1000/day) was the most commonly prescribed antibiotic, followed by cefixime (9.17 DDD/1000/ day) and amoxicillin and clavulanic acid (8.64 DDD/1000/day). Similar to our study, Mule et al..$^{17}$ reported higher consumption of azithromycin (107.83 DDD/1000/day) in their research. In contrast, a population-based study on trends of antibiotic use in Korea reported penicillins (mean consumption 4.52 DDD/1000/ day) as a commonly used antibiotic subgroup, followed by second-generation cephalosporins (4.47 DDD/1000/day), macrolides (3.32 DDD/1000/day), and fluoroquinolones (2.75 DDD/1000/day). ${ }^{18}$ Another study on antibiotic consumption in pediatric patients reported high consumption of penicillins (271.22 DDD/1000/day), followed by cephalosporins (98.46 DDD/1000/day) and macrolides (72.70 DDD/1000/day) in the pulmonology department. ${ }^{19}$ Bansal et al. ${ }^{20}$ reported higher consumption of ceftriaxone (143.22 DDD/1000 patient-days), followed by doxycycline (85.02 DDD/1000 patient-days) and azithromycin (66.37 DDD/1000 patient days, oral; 59.37 DDD/1000 patient days per oral).

We observed azithromycin as a drug of choice for upper respiratory tract infections. However, according to the WHO model list of essential medicines, azithromycin belongs to the Watch category and is the first-choice antibiotic for sexually transmitted infections such as gonorrhea, as well as cholera, ${ }^{21}$ amoxicillin and clavulanic acid were prescribed for pneumonia, urinary tract infections, and otitis media in our study. According to the WHO model list of essential medicines list, amoxicillin and clavulanic acid belong to the Access category. It is the preferred first-choice antibiotic for community-acquired pneumonia, skin and soft-tissue infections, lower urinary tract 
infections, hospital-acquired pneumonia, and COPD. It is the second-choice antibiotic for bone and joint infections, otitis media, and surgical prophylaxis. ${ }^{21}$ Cefixime was prescribed for bone and joint infections, chronic suppurative otitis media, and urinary tract infection. However, according to the WHO model list, cefixime belongs to Watch group antibiotics and is preferred as the second choice for acute diarrhea/dysentery and gonorrhea. ${ }^{21}$

We observed the absence of standard treatment guidelines for infectious diseases in the hospital. However, there was an approved hospital formulary list or essential medicines list in the hospital. A study by Atif et al. ${ }^{10}$ reported a similar result, whereas Shahbazi et al. ${ }^{7}$ reported contrasting results. Irrational prescribing or inappropriate prescribing of antibiotics is a crucial contributing factor to antimicrobial resistance. Standard Treatment Guidelines allow prescribers to follow the standard, avoid irrational prescribing, and provide quality patient care without any compromise. They also prevent unnecessary drug reactions and out-of-pocket expenditures to the patient and promote a faster recovery for the patient. The Treatment Guidelines for Antimicrobial Use in common syndromes, 2019 by the Indian Council of Medical Research 22 offer guidelines for antimicrobial use in common infectious diseases with dose, frequency of administration, duration, and monitoring antimicrobial use. They are available free of charge. Framed according to the Indian scenario, if followed, they help in preventing irrational or inappropriate antimicrobial use.

The main drawback was the absence of standard treatment guidelines in the hospital. Although the remaining indicators are satisfactory, prescribing without standards is worrying. According to the Indian Council for Medical Research, ${ }^{22}$ the preferred antimicrobial agent for pelvic inflammatory disease, and alternative antibiotic for typhoid fever, bacterial sinusitis was cefixime. However, in our study, cefixime was also prescribed for throat infection, upper respiratory tract infection, fever, chronic otitis media, etc. Ofloxacin was indicated for epididymo-orchitis, ${ }^{22}$ whereas it was prescribed for topical ulcer, alcoholic gastritis, and perianal infection. Likewise, standard treatment guidelines can prevent inappropriate prescribing practices.

In all, $98.3 \%$ of key antimicrobials were available in the hospital stores on the day of our study. Atif et al. ${ }^{10}$, Shahbazi et al. ${ }^{7}$, and Woldu et al. ${ }^{23}$ reported a lower percentage of key antimicrobial availability in the hospital stores on the day of their study (93.8\%, 90.1\%, and $78.5 \%$ respectively). The availability of key antimicrobials all the time is essential because the practitioners will start prescribing antimicrobials that are not indicated for the disease, or they may prescribe branded forms of critical antimicrobials for purchase from outside the hospital. Branded types of drugs are more economical and increase the out-ofpocket expenditures for the patient.

The average number of days that a set of essential antimicrobials was out of stock in our study was 3.2 days/month. Atif et al. ${ }^{10}$ reported a similar result (3.3 days/month). However, Shahbazi et al. $^{7}$ and Woldu et al. ${ }^{23}$ reported a high average number of out-of-stock days for essential antimicrobials (6.78 days/month and 15-45 days over a 12-month period). This indicator provides information about healthcare capacity and practices to maintain inventory control, procurement, and correct distribution. ${ }^{10}$

The average number of antibiotics prescribed per hospitalization in our study was 1.12. Atif et al. ${ }^{10}$, Shahbazi et al. ${ }^{7}$, and Osama and Ibrahim ${ }^{24}$ reported a higher average number of antibiotics than our study (2.35, 2.85, and 2.7, respectively). Antibiotics should be prescribed whenever needed and appropriate. However, in real situations, patients are unaware of antimicrobial resistance and influenced by false beliefs, and behavioral factors often cause them to ask the physician to prescribe an antibiotic or think that the physician is not competant if he/she does not prescribe an antibiotic. Patient awareness of antimicrobial resistance due to the irrational use of antibiotics can prevent these circumstances.

In our study, $98.00 \%$ of antibiotic prescription was consistent with the formulary list. Two other studies reported similar results. ${ }^{10,11}$ In contrast, Shahbazi et al. ${ }^{7}$ reported $100 \%$ consistency in prescription with the hospital formulary list. The hospital formulary list optimizes medication use. Lack of awareness of the formulary list among physicians, a deficiency of the listed antibiotics, or prescribing brand names instead of generic names may cause non-adherence to such hospital policy. ${ }^{22}$ Physicians will not prescribe the medication if they are unaware of the formulary list. This results in a waste of healthcare resources because the stocked drugs reach their expiry dates and become useless.

In our study, $98.00 \%$ of antibiotics were prescribed using the generic name. This prescribing practice was far better than those reported by Atif et al. ${ }^{10}$, Green et al. ${ }^{25}$, and Shahbazi et al. ${ }^{7}$ (52.5\%, 88\%, and $13.18 \%$, respectively). Prescribing drugs by their generic names is essential in developing countries because it lessens the economic burden on poor people. Patients' misconceptions about generic drugs versus brand drugs allow easy exploitation and make them prefer branded drugs over generic drugs. Moroever, prescribing generic drugs often prevents confusion surrounding multiple names assigned to the same product. ${ }^{16}$ Patients are also habituated to buy the drug with the same brand name only, although the same drug is available in generic form or under another brand. There is a need to strengthen the awareness of generic drugs and their availability among patients. In India, the central government set up a "Jan Aushadhi" scheme wherein pharmacies will sell generic drugs and all medicines so that pharmacies are affordable for the people.

The mean duration of antimicrobial treatment prescription was 5.24 days, and similar results were reported by Atif et al. ${ }^{10}$ and Shahbazi et al. ${ }^{7}$ (5.4 days and 5.65 days, respectively). The duration of antibiotic treatment varies according to the severity of the disease and the nature of the drug. Since there is no consensus on the optimal duration of therapy for the majority of infectious diseases, it is better to treat for at least 7-10 days. A short course of treatment may lead to antimicrobial-resistant 
microbes. At the same time, prolonged exposure increases the risk of adverse drug reactions, antimicrobial resistance, and also unwanted expenditure on antibiotics. ${ }^{16}$ The percentage of pneumonia patients prescribed antimicrobials according to standard treatment guidelines was $13.28 \%$. Shahbazi et al. ${ }^{7}$ reported $19.23 \%$ for the same figure. However, in our study, there was no use of standard treatment guidelines. Green et al. ${ }^{25}$ also reported that pneumonia patients in their study were prescribed antibiotics without any standard treatment guidelines.

Four antibiotics from the Access category and five antibiotics from the Watch category were prescribed in our study. The WHO's AWaRe classification specified that the antibiotics consumed from the Access group should be at least $60 \% .^{26}$ In our study, $46.80 \%$ of antibiotics from the Access category was prescribed. Watch group antibiotics accounted for $53.19 \%$ of the total antibiotics prescribed. This indicates the overuse of Watch group antibiotics. A study on pediatric antibiotic prescription in China also reported a similar practice of overuse. ${ }^{27} \mathrm{~A}$ pediatric survey reported varied consumption of $\mathrm{AWaRe}$ antibiotics among countries. Access group antibiotic consumption for children in Slovenia accounted for $61.2 \%$, whereas in China, it was $7.8 \%$. Watch group antibiotic consumption for children is highest in Iran (77.3\%), whereas it is lowest in Finland (23.0\%). In neonates, Singapore Access group antibiotics accounted for $100 \%$ of all those prescribed, whereas China registered the lowest consumption of Access group (24.2\%). ${ }^{28}$

\section{Study limitations}

The study has a few limitations. One of the hospital indicators, Expenditure on antimicrobials as a percentage of total hospital medicine costs, was not calculated due to administrative policies in the hospital. One of the prescribing indicators, the average cost of antimicrobials prescribed per hospitalization, was not calculated due to organizational policies. We collected data from outpatient departments only, so we are unable to calculate two prescribing indicators i.e., antimicrobials used in surgical prophylaxis and the average number of antibiotic doses administered for cesarean sections.

\section{CONCLUSION}

Our study observed irrational prescribing practices. Strict implementation of the use of standard treatment guidelines prevents inappropriate prescribing. Drugs should be prescribed by their generic names, and the percentage of antibiotics prescribed consistent with the hospital formulary should reach $100 \%$ for better results.

Conflicts of interest: No conflict of interest was declared by the authors. The authors alone are responsible for the content and writing of the paper.

\section{REFERENCES}

1. Hiltunen T, Virta M, Laine AL. Antibiotic resistance in the wild: an eco-evolutionary perspective. Philos Trans R Soc Lond Biol Sci. 2017;372:20160039.
2. Baur D, Gladstone BP, Burkert F, Carrara E, Foschi F, Do"bele S, Tacconelli E. Effect of antibiotic stewardship on the incidence of infection and colonisation with antibiotic-resistant bacteria and Clostridium difficile infection: a systematic review and meta-analysis. Lancet Infect Dis. 2017;17:990-1001.

3. Full text: G20 Leaders' Communique, Hangzhou Summit. Last Accessed Date: 25.02.2020. Available from: http://www.china.org.cn/ world/2016-09/06/ content_39245577.html

4. Naylor NR, Silva S, Kulasabanathan K, Atun R, Zhu N, Knight GM, Robotham JV. Methods for estimating the burden of antimicrobial resistance: a systematic literature review protocol. BMC Syst Rev. 2016;5:187-192.

5. Zhussupova G, Skvirskaya G, Reshetnikov V, Dragojevic-Simic V, Rancic $N$, Utepova D, Jakovljevic M. The evaluation of antibiotic consumption at the inpatient level in Kazakhstan from 2011 to 2018. Antibiotics (Basel). 2020;9:57.

6. Gurtler N, Erba A, Giehl C, Tschudin-Sutter S, Bassetti S, Osthoff M. Appropriateness of antimicrobial prescribing in a Swiss tertiary care hospital: a repeated point prevalence survey. Swiss Med Wkly. 2019;149:w20135.

7. Shahbazi Nia S, Hiremath SRR, Prasad S. Assessment of Antimicrobial use pattern using World Health Organization prescribing indicators at a tertiary hospital: a prospective, observational study. J App Pharm Sci. 2018;8:132-138.

8. Yan K, Xue M, Ye D, Yang C, Chang J, Jiang M, Zhao M, Zhang H, Fang $Y$. Antibiotic prescribing practices in secondary and tertiary hospitals in Shaanxi province, western China, 2013-2015. PLoS One. 2018;3:e0207229.

9. Wattal C, Khanna S, Goel N, Oberoi JK, Rao BK. Antimicrobial prescribing patterns of surgical speciality in a tertiary care hospital in India: role of persuasive intervention for changing antibiotic prescription behaviour. Indian J Med Microbiol. 2017;35:369-375.

10. Atif M, Azeem M, Saqib A, Scahill S. Investigation of antimicrobial use at a tertiary care hospital in Southern Punjab, Pakistan using WHO methodology. Antimicrob Resist Infect Control. 2017;6:41.

11. Atif M, Azeem M, Sarwar MR, Shahid S, Javaid S, Ikram H, Baig U, Scahill S. WHO/INRUD prescribing indicators and prescribing trends of antibiotics in the Accident and Emergency Department of Bahawal Victoria Hospital, Pakistan: Springerplus; 2016;5:1928.

12. Wang $J$, Wang $P$, Wang $X$, Zheng $Y$, Xiao $Y$. Use and prescription of antibiotics in primary health care settings in China. JAMA Intern Med. 2014;174:1914-1920.

13. Kotwani A, Holloway K. Trends in antibiotic use among outpatients in New Delhi, India. BMC Infect Dis. 2011;11:99.

14. WHO. Executive summary: the selection and use of essential medicines. Report of the 21st WHO Expert Committee on the Selection and Use of Essential Medicines.2017. Last Accessed Date: 25.02.2020. Available from: http://www.who.int/medicines/publications/essentialmedicines/ EML_2017_ExecutiveSummary.pdf

15. Sharland M, Pulcini C, Harbarth S, Zeng M, Gandra S, Mathur S, Magrini N. Classifying antibiotics in the WHO Essential Medicines List for optimal use-be AWaRe. Lancet Infect Dis. 2018;18:18-20.

16. Strengthening Pharmaceutical Systems. 2012. How to Investigate Antimicrobial Use in Hospitals: Selected Indicators. Published for the U.S. Agency for International Development by the Strengthening Pharmaceutical Systems Program. Arlington, VA: Management Sciences for Health. 
17. Mule AV, Sharma MC, Raghunath A, Deshpande PR. A survey of antibiotics dispensing pattern in a community pharmacy of Pune city. $J$ Sci Soc. 2018;45:119-124.

18. Yoon YK, Park GC, An H, Chun BC, Sohn JW, Kim MJ. Trends of antibiotic consumption in korea according to national reimbursement data (20082012): a population-based epidemiologic study. Medicine (Baltimore). 2015;94:e2100.

19. Bytyqi $H Q$, Hoxha R, Bahtiri E, Krasniqi V, Krasniqi S. Antibiotic Utilization in Pediatric Hospitalized Patients - A Single Center Study. Open Access Maced J Med Sci. 2017;5:256-260.

20. Bansal D, Mangla S, Undela K, Gudala K, D'Cruz S, Sachdev A, Tiwari P. Measurement of adult antimicrobial use in tertiary care hospital using defined daily dose and days of therapy. Indian J Pharm Sci. 2014;76:211217.

21. World Health Organization Model List of Essential Medicines, 21st List, 2019. Geneva: World Health Organization; 2019. Licence: CC BY-NC-SA 3.0 IGO.

22. Treatment Guidelines for Antimicrobial Use in Common Syndromes. 2nd ed. New Delhi: Indian Council of Medical Research; 2019. Last Accessed Date: 29.03.2020. Available from: https://www.icmr.nic.in/guidelines

23. Woldu MA, Suleman S, Workneh N, Berhane H. Retrospective study of the pattern of antibiotic use in Hawassa University referral hospital pediatric ward, Southern Ethiopia. J Appl Pharm Sci. 2013;3:93-98.
24. Osama H. Ibrahim M. Evaluation of Drug and Antibiotic Utilization in an Egyptian University Hospital: An Interventional Study. Intern Med. 2012;2:1-3.

25. Green T, Omari Z, Siddiqui Z, Anwari J, Noorzaee A. 2010. Afghanistan Medicine Use Study: A Survey of 28 Health Facilities in 5 Provinces. Submitted to the U.S. Agency for International Development by the Strengthening Pharmaceutical Systems (SPS) Program. Arlington, VA: Management Sciences for Health.

26. World Health Organization. Proposed programme budget 2020-2021: Thirteenth General Programme of Work, 2019-2023. Geneva: World Health Organization; 2018.

27. Wang CN, Huttner BD, Magrini N, Cheng Y, Tong J, Li S, Wan C, Zhu Q, Zhao S, Zhuo Z, Lin D, Yi B, Shan Q, Long M, Jia C, Zhao D, Sun X, Liu J, Zhou Y, Li R, Liu J, Zhu Y, Miao R, Zhu C, Qi Z, Wang C, Wu S, Xu X, Zhou L, Ye W, Luo N, Gao H, Yang P, Bieerding M, Tang J, Zeng M; Collaborative Working Group of the Pediatric Subgroup of the China Society of Infectious Diseases. Pediatric Antibiotic Prescribing in China According to the 2019 World Health Organization Access, Watch, and Reserve (AWaRe) Antibiotic Categories. J Pediatr. 2020;220:125-131.e5.

28. Hsia Y, Lee BR, Versporten A, Yang Y, Bielicki J, Jackson C, Newland J, Goossens H, Magrini N, Sharland M; GARPEC and Global-PPS networks. Use of the WHO Access, Watch, and Reserve classification to define patterns of hospital antibiotic use (AWaRe): an analysis of paediatric survey data from 56 countries. Lancet Glob Health. 2019;7:e861-e871. 